\title{
Follitropin Subunit Beta
}

National Cancer Institute

\section{Source}

National Cancer Institute. Follitropin Subunit Beta. NCI Thesaurus. Code C104399.

Follitropin subunit beta (129 aa, $15 \mathrm{kDa}$ ) is encoded by the human FSHB gene. This protein plays a role in induction of egg and sperm production. 